Rev. Biol. Trop., 48(2/3): 317-322, 2000

www.ucr.ac.cr www.ots.ac.cr www.ots.duke.edu

\title{
A new species of Trapania (Nudibranchia: Goniodorididae) from the Pacific coast of Central America
}

\author{
Yolanda Camacho-García ${ }^{1}$ and Jesús Ortea ${ }^{2}$ \\ 1 Academia de Ciencias, California, Golden Gate Park, San Francisco, California 94118. Fax: 415-750-7090. \\ E-mail: ycamacho-garcia@calacademy.org \\ 2 Departamento de Biología de Organismos y Sistemas, Laboratorio de Zoología, Universidad de Oviedo, \\ c§ Catedrático Rodrigo Uría s§n, 33071 Oviedo, Spain. Fax: (348) 5104868. E-mail: kankel@ teleline.es
}

Received 8-I-2000. Corrected 10-II-2000. Accepted 8-III-2000.

\begin{abstract}
A new marine gastropod species of the genus Trapania Pruvot-Fol, 1931, is described from Cabo Blanco, Puntarenas, Costa Rica and from Islas Secas, Panamá. Trapania inbiotica sp. nov. has a white body with red patches, white rhinophores with some little red patches, yellow appendages with partially red bases. The radula is composed of 28 rows of teeth. Each tooth has a large conical cusp with 21-24 denticles. Two or three of those denticles on the inner side of the cusp are smaller than the others. There are also 1-3 small denticles on the outside of the cusp. The jaw elements are very irregular.
\end{abstract}

Key words: Mollusca, Opisthobranchia, Nudibranchia, Goniodorididae, Trapania, Costa Rica, Panamá, Pacific Ocean.

The genus Trapania Pruvot-Fol, 1931, comprises seven valid Pacific species. The first reference to the genus from the Pacific Ocean was the description of Trapania velox from California by Cockerell (1901). Later, Baba (1935) introduced Trapania japonica, from Japan, and Miller (1981) described Trapania rudmani, a new species from New Zealand. Rudman (1987) revised the genus Trapania from the Indo-West Pacific. According to Rudman there are seven valid species in this area including Trapania japonica, which was later redescribed by Baba (1990).

Until now, Trapania velox (Cockerell 1901) was the only member of the genus Trapania reported from the Pacific coast of the Americas. The present paper describes a second species of this genus from the Pacific Coast of Costa Rica and Panamá.

\section{SPECIES DESCRIPTION}

Family Goniodorididae $\mathrm{H}$. and A. Adams, 1854

Genus Trapania Pruvot-Fol, 1931

Trapania inbiotica, sp. nov.

(Figs 1-3)

Type Material: Holotype: INBio CRI00150088, Estación San Miguel, Reserva Absoluta de Cabo Blanco (Area de Conservación Tempisque), Cabuya, Cóbano, Puntarenas, Costa Rica $\left(9^{\circ} 34^{\prime} 49^{\prime}\right.$ N, 8508'28”'W), 16 May, 1998; 1 specimen 2.5 $\mathrm{mm}$ preserved length, collected by snorkeling in the intertidal rocky shore under rocks, $1 \mathrm{~m}$ depth.

Paratype: CASIZ 088159, $3 \mathrm{~km}$ South of anchorage, Islas Secas, Pacific coast of Panamá, 22 April 1993; 1 specimen $6 \mathrm{~mm}$ preserved length, $11 \mathrm{~m}$ depth collected by Terry Gosliner. 


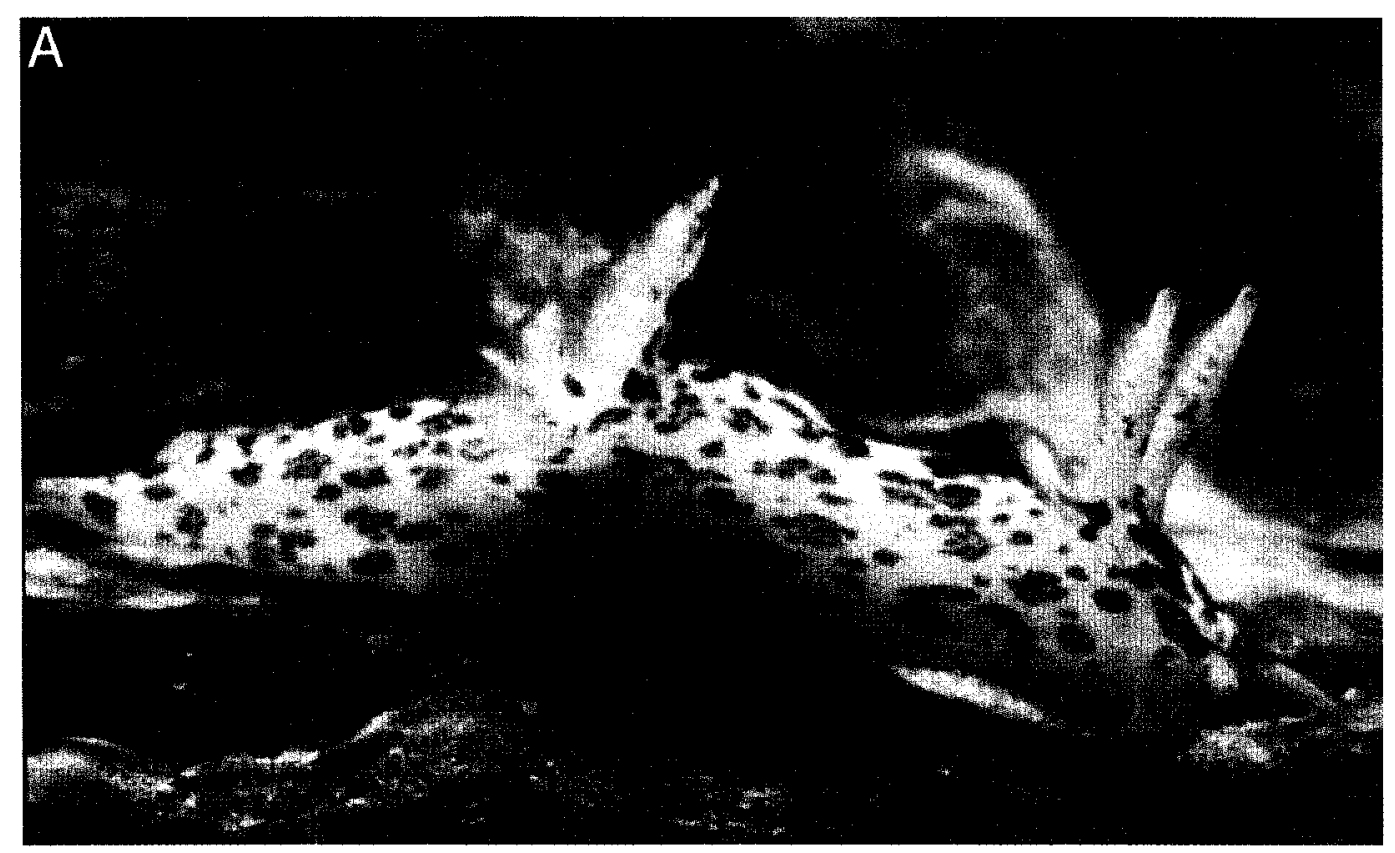

B

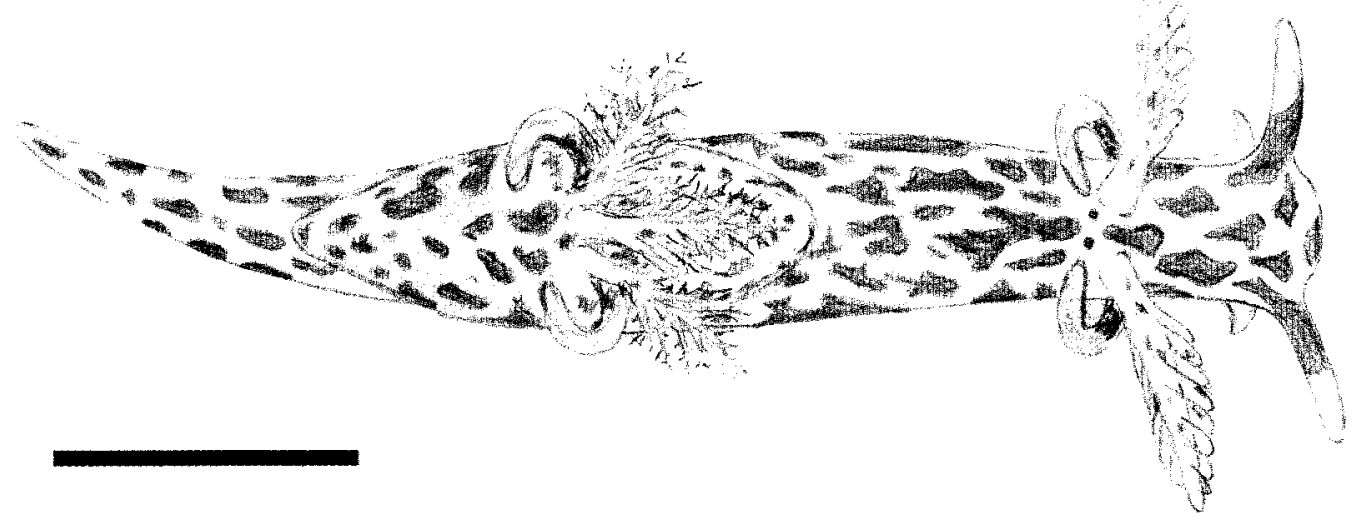

Fig. 1. A. Living animal. Holotype (INBio CRI00150088).B. Dorsal view; scale bar=2mm.

External Morphology: The length of the living animal is $10 \mathrm{~mm}$. The body is limaciform, soft and elongate. There is an extra-branchial appendage situated alongside each rhinophore and an extrabranchial appendage on each side of the gill. The two pairs of dorsolateral extra-rhinophoral and extra-branchial appendages are digitiform, equal in size and shorter than the rhinophores and branchial leaves. The rhinophores have a lamellate club with 9-10 very wide lamellae.
The gill consists of three tripinnate branchial leaves arranged perpendicularly to the body, located about halfway down the body in the dorsal midline. The axis of the rhinophores and the rachis of the branchial leaves are conical. There is a pair of relatively short oral tentacles at the end of the head, and below the leading edge of the foot is extended laterally into tentacular foot corners. The pointed posterior end of the foot is about one fifth of the length. 
The general color of the body is white with irregular red patches arranged over the entire dorsum (Figs 1A-B). The patches vary in shape and size. The larger ones are located dorsally, from the head to the gills, and are generally composed of an aggregate of red punctations. The smaller ones are located on the lateral portions of the body. The rhinophores are white with some little red spots. The bases of the extrarhinophoral and extrabranchial appendages are basally red with the rest of the legth yellow. The branchial leaves are white. The anterior and posterior sides of the rachis have some red or yellow spots. The labial papillae are yellow with red bases. The foot is white, however the tentacular foot corners are white with yellow and red spots in the bases.
Jaws: The radular formula is $28 \mathrm{x}(1.0 .1)$. The radula consists of two series of 28 elongated teeth. Each tooth has a large, conical cusp (or a large denticle) which is displaced towards the side of the radula. The teeth increase in size from the oldest to the newest end of the ribbon. There are usually 1-3 small denticles outside the cusp and 21-24 on the inside. Two or three of those denticles inside the cusp are smaller than the others (Figs 2A$B$ ). The jaws have a number of irregular elements (Fig 2C).

Reproductive System: The thick hermaphroditic duct leads to a pyriform ampulla. It joins the prostatic portion of the vas deferens, which is short and wider in the middle

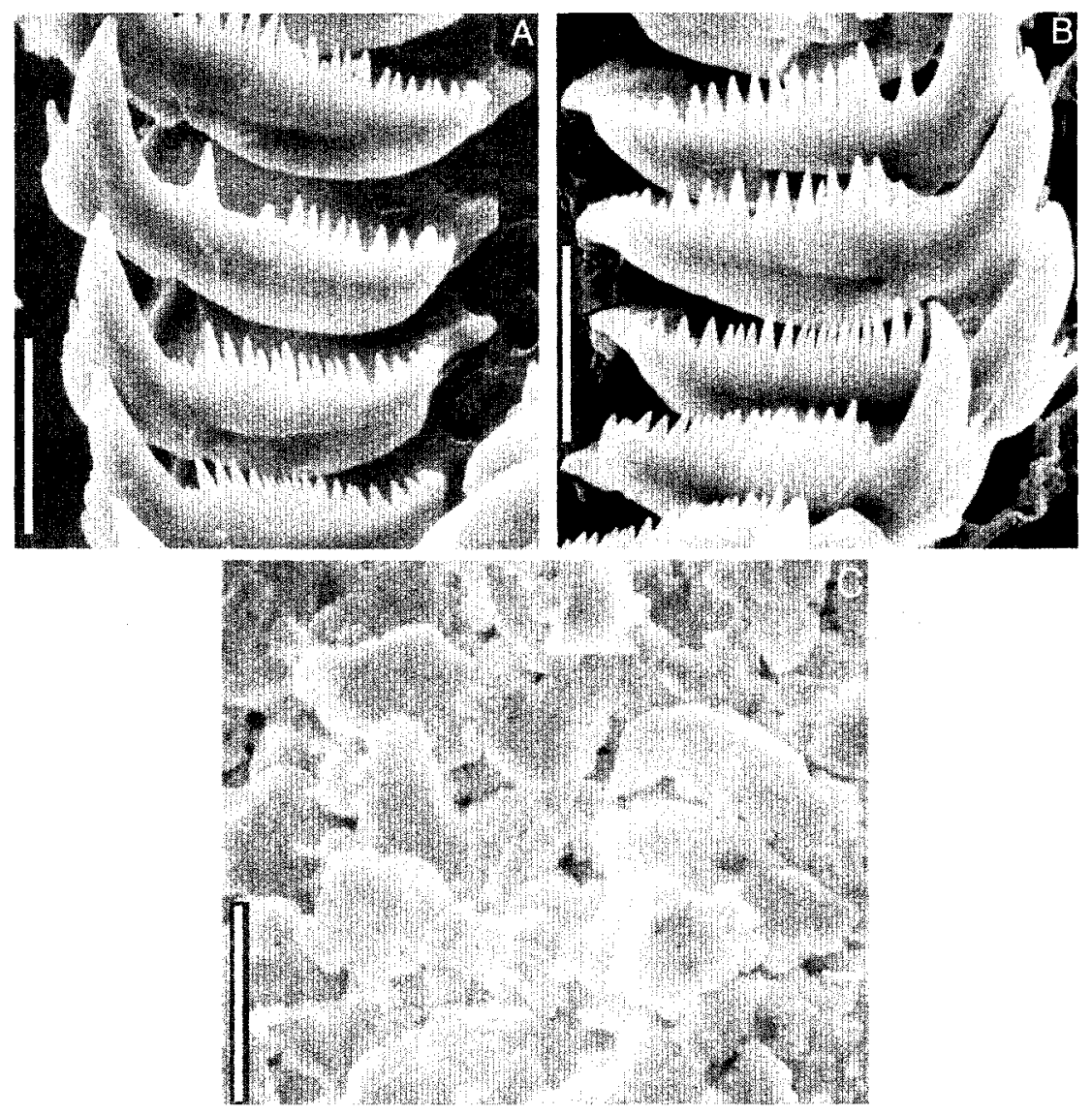

Fig. 2. Radular morphology of the holotype (INBio CRI001 50088). A. Teeth of the oldest end of the ribbon, scale bar= 150 $\mu$ m; B. Teeth of the newest end of the ribbon; scale bar $=150 \mu \mathrm{m}$. C. Jaw elements, scale bar $=7.5 \mu \mathrm{m}$. 
A

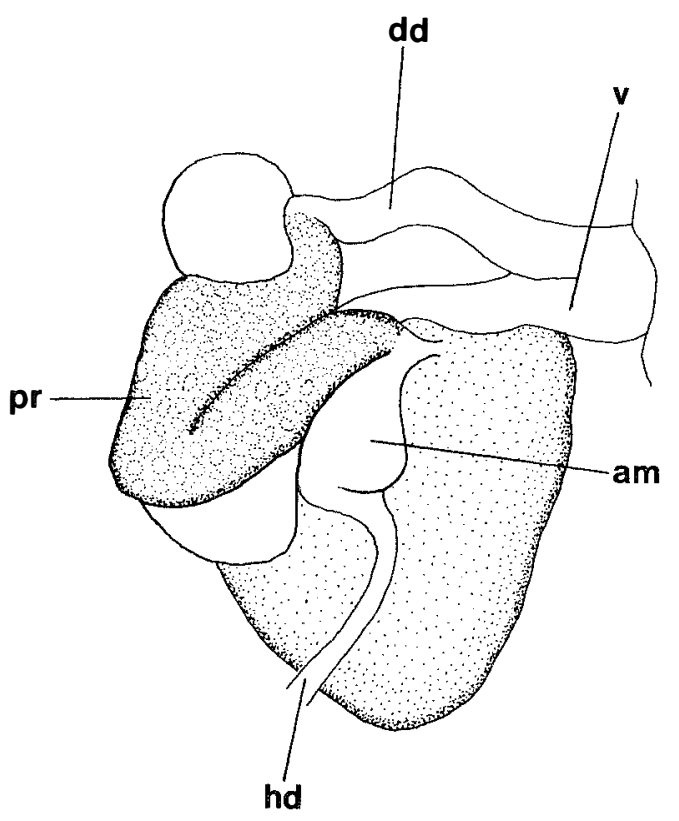

B

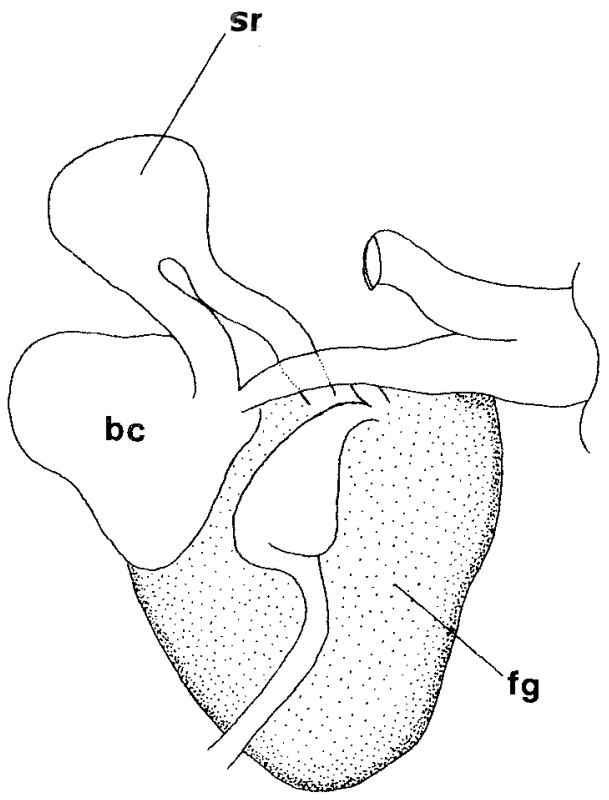

C

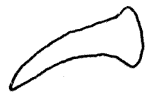

d

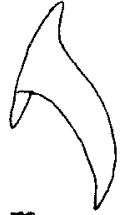

m

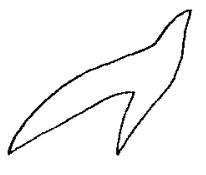

p

Fig. 3. Reproductive system of the holotype (INBio CRI00150088). A. Dorsal view with the prostate, scale bar=0.5mm.B. Dorsal view without the prostate, scale bar $=0.5 \mathrm{~mm}$. C. Penial spine, scale bar $=0.01 \mathrm{~mm}$. Abbreviations: am=ampulla, $b c=$ bursa copulatrix, $d=$ distal penial spine, $d d=$ deferent duct, $f g=$ female gland, $s r=s e m i n a l$ receptacle, hd=hermaphrodite duct, $\mathrm{m}=$ middle penial spine, $\mathrm{p}=$ proximal penial spine, $\mathrm{pr}=$ prostate, $\mathrm{v}=\mathrm{vagina}$.

part. The proximal oviduct is short. The deferent duct is long and narrow and opens into a common atrium with the vagina. The penis is composed of 20 rows of penial hooks of different sizes and shapes. The distal hooks are smaller and less curved than those in the middle, which are more curved and conical. In constrast, the proximal hooks are bigger than those in the middle but less curved (Fig. $3 \mathrm{C})$. The long and wide vagina connects to the large and irregular shaped bursa copulatrix. From the bursa copulatrix leads another 
wide duct that connects to the seminal receptacle and the uterine duct. The bursa copulatrix is about twice as large as the seminal receptacle (Figs 3A-B).

Etymology: The name of this species is a combination of "INBio" (Instituto Nacional de Biodiversidad) and "tica" the feminine gender of the colloquial term used for the Costa Rican things and people. We want to conmemorate INBio on its tenth anniversary (October, 1999) dedicated to the conservation of the Costa Rican Biodiversity.

\section{DISCUSSION}

Trapania velox (Cockerell 1901) is the only valid species of the genus Trapania reported from the Pacific coast of the Americas. MacFarland (1966) and McDonald (1983) redescribed this species based on specimens from California with a length between 15 to $25 \mathrm{~mm}$. According to these authors, Trapania velox has yellow to orange rhinophores, anterior tentacles, branchial leaves, extrabranchial appendages and tail. The body is marked with dark brown lines extending down the midline and on to the extra-branchial appendages, down the tail and along the sides (MacFarland 1966). In contrast, $T$. inbiotica has white rhinophores speckled with red. The appendages and oral tentacles are yellow distally and red proximally. The posterior portion of the foot is white with red patches. Another difference between these species is that the radular formula of $T$. velox as described by MacFarland (1966) is $24 \mathrm{x}(1.0 .1)$ and by McDonald (1983) is $22 \times(1.0 .1)$, whereas that of our species is $28 x(1.0 .1)$. In T. velox, each tooth has a long pointed cusp and, unlike $T$. inbiotica, there are not denticles outside the inner edge of it. The number of the unequal sharp denticles inwards from the cusp is only 811, instead of 21-24 as in T. inbiotica. Trapania velox has about 2 larger denticles close to the cusp which are larger than the others. In $T$. inbiotica these denticles are smaller than the others.
There is another unnamed species of Trapania (see Bertsch \& Kerstitch, 1984, Bertsch in Kerstitch, 1989) from the Pacific coast of the Americas. It is being described by Millen and Bertsch (in press, TheVeliger), and differs significantly from our new species in external coloration and morphology, radular morphology and meristics, and details of the reproductive system.

The Indo-West Pacific species described by Rudman (1987) and Miller (1981) are different in color from our species. Trapania aureopunctata Rudman, 1987, T. toddi Rudman, 1987, $T$. aurata Rudman, 1987, T. davelli Rudman, 1987 and T. rudmani Miller, 1981 have a white body marked with yellow and brown. Others, like $T$. brunnea Rudman, 1987, T. benni Rudman, 1987 and $T$. reticulata, Rudman,1987 are brown with white and yellow patches. Also, the radular morphology of these species is very different from those of $T$. inbiotica. Trapania japonica Baba, 1935 is the only species that, externally is similar to $T$. inbiotica, because of the white color of the body and the arrangement of the brown spots. However, the radular teeth of $T$. japonica have a median main cusp which is flanked by a row of denticles on each side, those of $T$. inbiotica have the cusp situated further of the outer edge.

\section{ACKNOWLEDGEMENTS}

The authors are grateful to the members of the "II Taller Internacional de Moluscos Marinos" and the Reserva Natural Absoluta de Cabo Blanco for their support during the workshop. We are indebted to Terry Gosliner who provided us with the material from Panamá and Ángel Valdés who helped in several aspects of this paper. Leopoldo Moro Abad photographed the living animal. The electron microscope work was done at the California Academy of Sciences and the Unidad de Microscopía Electrónica (Universidad de Costa Rica). This research was financed by the 
Norwegian Agency for Development Cooperation (NORAD) through the project "Development of Biodiversity Knowledge and Sustainable Use in Costa Rica" conducted by the National Biodiversity Institute of Costa Rica (INBio). This research was also possible thanks to the Cooperation Agreement between the Ministry of Environment and Energy (MINAE) and INBio.

\section{RESUMEN}

A partir de dos ejemplares recolectados en la costa pacífica de Costa Rica y Panamá, se describe una nueva especie Trapania inbiotica sp. nov., la cual se distingue por tener el cuerpo blanco con manchas rojas y rinóforos blancos con algunas manchas amarillas pequeñas. La rádula está compuesta por 28 filas de dientes donde cada diente tiene de 21-25 dentículos y una cúspide cónica y larga situada cerca del lado exterior. Dos o tres de esos dentículos localizados en la parte interna de la cúspide son más pequeños que los otros. También están presentes de 1-3 dentículos en la parte externa de la cúspide. La armadura labial está compuesta por uncinos muy irregulares.

\section{REFERENCES}

Baba, K. 1935. Report of the Biological Survey of Mutsu Bay (27) Nudibranchia of Mutsu Bay. Science Report of the Tohoku Imperial University, Fourth Series, Biology. Vol. X, No.2, Sendai, Japan.

Baba, K. 1990. Notes on the rare genera Trapania and Ancula from Japan with the description of a new species (Nudibranchia: Goniodorididae). Venus 49: 8-18.
Behrens, D. 1991. Pacific Coast Nudibranchs: A guide to the Opisthobranchs, Alaska to Baja California. Sea Challengers, Monterey, California. 107 p.

Bertsch, H. 1989. Opisthobranchia. In: Kerstitch, A.,1989, Sea of Cortez Marine Invertebrates. Sea Challengers, Monterey, California. 54-68 p.

Bertsch, H. \& A. Kerstitch, 1984. Distribution and radular morphology of various nudibranchs (Gastropoda: Opisthobranchia) from the Gulf of California, Mexico. Veliger 26: 264-273.

Cockerell, T.D.A. 1901. Three new nudibranchs from California. J. Malacol. 8: 85-87.

MacFarland, F.M. 1966. Studies of opisthobranchiate mollusks of the Pacific coast of North America. Mem. Calif. Acad. of Sci. 6: 1-546.

McDonald, G. R. 1983. A review of the nudibranchs of the California coast. Malacologia 24: 114-276.

Millen, S.V. \& H. Bertsch. 1999. Three new nudibranchs (Opisthobranchia: Doridacea) from southern California, U.S.A., and the Baja California peninsula, Mexico. Veliger (in press).

Miller, M.C. 1981. Trapania rudmani, a new dorid nudibranch (Gastropoda: Opisthobranchia) from New Zealand. New Zeal. J. Zool. 8: 5-9.

Rudman, W.B. 1987. The genus Trapania (Nudibranchia, Goniodorididae) in the Indo-West Pacific. J. Moll. Stud. 53: 189-212. 